\title{
IN VENTORIES
}

nP

THE WARDROBES, PLATE, CHAPEL STUFF, ETC.

or

\section{IENRY FITZROY, DUKE OF RICHMOND,}

AND OF

THE WARDROBE STUFF AT BAYNARD'S CASTLE

or

\section{KATHARINE, PRINCESS DOWLGER.}

EDITED, WITH $\Lambda$

MEMOIR AND LETTERS OF THE DUKE OF RICHMOND,

BY JOHN GOUGH NICHOLS, F.S.A.

PRINTED FOR THE CAMDEN SOCIETY.

M.DCCC.LY. 